\title{
Commentary \\ Maintenance of tracheal tube cuff pressure: where are the limits?
}

Miquel Ferrer and Antoni Torres

\begin{abstract}
Unidad de Cuidados Intensivos e Intermedios Respiratorios, Servei de Pneumologia, Institut Clinic del Torax, Hospital Clinic, Institut d'Investigacions Biomediques August Pi I Sunyer (IDIBAPS), CibeRes (ISCiii-CB06/06/0028), Barcelona, Spain
\end{abstract}

Corresponding author: Antoni Torres, atorres@ub.edu

Published: 16 January 2008

This article is online at http://ccforum.com/content/12/1/106

(c) 2008 BioMed Central Ltd

See related research by Nsier et al., http://ccforum.com/content/11/5/R109

\begin{abstract}
Continuous control of tracheal tube cuff inflation using a pneumatic device resulted in severe tracheal wall damage in ventilated piglets. This damage was similar in piglets managed with manual control of cuff inflation. The periodic hyperinflation of the tube cuff used in both groups of this study may explain these results. This manoeuvre should be avoided in clinical practice.
\end{abstract}

In a previous issue of Critical Care, Nseir and colleagues presented an article regarding continuous control of endotracheal cuff pressure and tracheal wall damage [1].

Among the pathogenic mechanisms responsible for ventilator-associated pneumonia (VAP), oropharyngeal colonization by potentially pathogenic microorganisms and silent aspiration of subglottic secretions around the tracheal tube cuff seem to play a pivotal role [2]. In order to prevent pneumonia, several approaches have been proposed - such as placing patients in the semirecumbent position [3], continuous aspiration of subglottic secretions (CASS) above the tracheal tube cuff [4], oropharyngeal decontamination by antiseptics [5], and the application of antiseptic-impregnated endotracheal tubes [6].

The key element of the proposed pathogenesis of VAP appears to be aspiration of colonized oropharyngeal and subglottic secretions. Appropriate control of the endotracheal tube cuff pressure $\left(P_{\text {cuff }}\right)$ may therefore serve as a major prevention target. Intubated patients were recommended to be managed with $P_{\text {cuff }}$ values between 20 and $30 \mathrm{cmH}_{2} \mathrm{O}$ to provide a sufficient seal without compromising mucosal perfusion [7]. The routine management of cuff inflation consists of periodic manual checking of the $P_{\text {cuff, }}$, which does not ensure the appropriate maintenance of the $P_{\text {cuff }}$ during continuous tracheal intubation [8]. Moreover, the manual
Critical Care 2008, 12:106 (doi:10.1186/cc6194) 
We have described a simple and cheap device that is very effective for the routine maintenance of adequate cuff inflation during mechanical ventilation that does not require any specific equipment [11]. A recent randomized clinical trial in mechanically ventilated patients comparing this device with the routine manual control of cuff inflation, however, showed no benefits in the prevention of VAP [12]. These findings suggest that other factors than cuff inflation influence the microaspiration of secretions to the lower airways around the tracheal tube cuff. Commercially available high-volume lowpressure tracheal tubes such as those used in the study often form folds around the cuff, hence allowing leakage of secretions pooled above the tube cuff in studies in vitro, even at $P_{\text {cuff }}$ levels similar to those used by Nseir and colleagues in piglets [13]. Several devices have consequently been recently developed in order to overcome this problem. Among those devices, the Microcuff endotracheal highvolume low-pressure tube features an ultrathin $(7 \mu \mathrm{m})$ polyurethane cuff membrane around an inner conventional inflatable cuff. This tube is effective in preventing fluid leakage around the cuff in an in vitro setup [14]. The combination of this device with CASS is effective in preventing both earlyonset and late-onset VAP in a recent clinical study [15].

One of the potential concerns of all these devices, particularly CASS, is the potential damage of the tracheal wall. In an animal sheep model, Berra and colleagues demonstrated important tracheal lesions when using CASS [16]. We do not know whether this is applicable to humans. In the study by Nseir and colleagues, the tracheal lesions found could be explained, at least in part, by the high inflation pressure they applied eight times daily via $50 \mathrm{ml}$ during $30 \mathrm{~min}$. This is not the current clinical practice in humans, and after this study it should be completely avoided.

\section{Competing interests}

The authors declare that they have no competing interests.

\section{Acknowledgements}

The present study was supported by CibeRes (ISCiii-CB06/06/0028), FIS 02-0744, SEPAR 2001, and 2005 SGR 00822.

\section{References}

1. Nseir S, Duguet A, Copin MC, De Jonckheere J, Zhang M, Similowski T, Marquette $\mathrm{CH}$ : Continuous control of endotracheal cuff pressure and tracheal wall damage: a randomized controlled animal study. Crit Care 2007, 11:R109.

2. Bonten MJ, Kollef MH, Hall JB: Risk factors for ventilator-associated pneumonia: from epidemiology to patient management. Clin Infect Dis 2004, 38:1141-1149.

3. Drakulovic MB, Torres A, Bauer TT, Nicolas JM, Nogue S, Ferrer M: Supine body position as a risk factor for nosocomial pneumonia in mechanically ventilated patients: a randomised trial. Lancet 1999, 354:1851-1858.

4. Valles J, Artigas A, Rello J, Bonsoms N, Fontanals D, Blanch L, Fernandez R, Baigorri F, Mestre J: Continuous aspiration of subglottic secretions in preventing ventilator-associated pneumonia. Ann Intern Med 1995, 122:179-186.

5. Chlebicki MP, Safdar N: Topical chlorhexidine for prevention of ventilator-associated pneumonia: a meta-analysis. Crit Care Med 2007, 35:595-602.
6. Rello J, Kollef M, Diaz E, Sandiumenge A, del CY, Corbella X, Zachskorn R: Reduced burden of bacterial airway colonization with a novel silver-coated endotracheal tube in a randomized multiple-center feasibility study. Crit Care Med 2006, 34:27662772.

7. Sengupta P, Sessler DI, Maglinger P, Wells S, Vogt A, Durrani J, Wadhwa A: Endotracheal tube cuff pressure in three hospitals, and the volume required to produce an appropriate cuff pressure. BMC Anesthesio/ 2004, 4:8.

8. Rello J, Sonora R, Jubert P, Artigas A, Rue M, Valles J: Pneumonia in intubated patients: role of respiratory airway care. $\mathrm{Am} J$ Respir Crit Care Med 1996, 154:111-115.

9. Guidelines for the management of adults with hospitalacquired, ventilator-associated, and healthcare-associated pneumonia. Am J Respir Crit Care Med 2005, 171:388-416.

10. Miller DM: A pressure regulator for the cuff of a tracheal tube. Anaesthesia 1992, 47:594-596.

11. Farre R, Rotger M, Ferrer M, Torres A, Navajas D: Automatic regulation of the cuff pressure in endotracheally-intubated patients. Eur Respir J 2002, 20:1010-1013.

12. Valencia M, Ferrer M, Farre R, Navajas D, Badia JR, Nicolas JM, Torres A: Automatic control of tracheal tube cuff pressure in ventilated patients in semirecumbent position: a randomized trial. Crit Care Med 2007, 35:1543-1549.

13. Young PJ, Rollinson M, Downward G, Henderson S: Leakage of fluid past the tracheal tube cuff in a benchtop model. $\mathrm{Br} J$ Anaesth 1997, 78:557-562.

14. Dullenkopf $A$, Gerber $A$, Weiss M: Fluid leakage past tracheal tube cuffs: evaluation of the new Microcuff endotracheal tube. Intensive Care Med 2003, 29:1849-1853.

15. Lorente L, Lecuona M, Alejandro J, Maria M, Antonio S: Influence of an endotracheal tube with polyurethane cuff and subglottic drainage on pneumonia. Am J Respir Crit Care Med 2007, 176:1979-1783.

16. Berra L, De Marchi L, Panigada M, Yu ZX, Baccarelli A, Kolobow $\mathrm{T}$ : Evaluation of continuous aspiration of subglottic secretion in an in vivo study. Crit Care Med 2004, 32:2071-2078. 